\title{
A Rare Case of Multiple Gastric Duplication Cysts in an Adult
}

\author{
Baris Zulfikaroglu' ${ }^{1}$, Ozgur Akgul ${ }^{1}$, Mahir Ozmen ${ }^{1,2,3}$ \\ ${ }^{1}$ General Surgery, Ankara Numune Teaching and Research Hospital, Ankara, Turkey \\ 2 Istinye University Medical School, General Surgery, Istanbul, Turkey \\ ${ }^{3}$ General Surgery, Liv Hospital, Ankara, Turkey
}

\begin{abstract}
Intestinal duplications are rare developmental anomalies that can occur anywhere along the gastrointestinal tract. Gastric duplication cysts are uncommon congenital anomalies and are rarely diagnosed in adults. However, diagnosis of the condition in an adult can be difficult, as it is usually asymptomatic, or the symptoms are nonspecific. Here we report a rare case of symptomatic Gastric duplication cysts in an adult who was treated successfully with surgical resection.
\end{abstract}

Keywords: gastric duplication cyst; gastrointestinal duplication, adult, gastric surgery

Cite this article as: Zulfikaroglu B, Akgul O, Ozmen M. A Rare Case of Multiple Gastric Duplication Cysts in an Adult. Turk J Surg 2020; DOl: 10.47717/turkjsurg.2020.4933.

\section{Corresponding Author \\ Baris Zulfikaroglu \\ E-Mail: zbaris61@gmail.com \\ Received: 23.06 .2020 \\ Accepted: 27.08 .2020 \\ Available Online: 08.12 .2020}

( ) Copyright 2020 by Turkish Surgical Society. Available online at www.turkjsurg.com

DOI: $10.47717 /$ turkjsurg.2020.4933

\section{INTRODUCTION}

Intestinal duplications are rare developmental anomalies that can occur anywhere along the gastrointestinal tract. Intestinal duplications were originally described in 1941, by Ladd and Gross, as having an attachment or adherence to some part of the gastrointestinal tract, the presence of a smooth muscle wall and a mucosal lining with one or more cell type of the gastrointestinal tract (1).

These malformations are believed to be congenital, formed before the differentiation of epithelial lining, and therefore named for the organ with which they are associated. Duplication cysts of the stomach represent four per cent of all alimentary tract duplications. Approximately 67 per cent of gastric duplication cysts (GDCs) are identified within the first year of life. Duplication cysts in adults are generally asymptomatic and encountered as incidental findings at endoscopy or laparotomy (2).

GDCs are uncommon congenital anomalies and are rarely diagnosed in adults. Alimentary tract duplication cysts most frequent affect the ileum (35\%), the esophagus (19\%), the jejunum (10\%), the stomach (9\%) and the colon (7\%) (3). In 35\% of patients, GDCs coexist with other congenital abnormalities such as annular or heterotopic pancreas, or vertebral anomalies such as spina bifida (3). On consideration of the fact that these cysts are usually asymptomatic or, in any case, have no specific signs and symptoms, diagnosis is frequently made post-operatively (3). Presentation in adults is uncommon as individuals with gastrointestinal duplication are usually asymptomatic or have nonspecific symptoms. A gastric duplication cyst can be complicated by intra cystic hemorrhage, ulceration, infection, mechanical obstruction, and rarely, malignancy (4).

Here we report a rare case of symptomatic GDC in an adult who was treated successfully with surgical resection.

\section{CASE REPORT}

A 19-year old female presented with a four-month history of intermittent epigastric discomfort associated with progressively increasing back and left upper quadrant abdominal pain. Review of systems revealed weight loss of approximately $7 \mathrm{~kg}$. Her past medical history and family history was not significant.

Ultrasonography demonstrated the presence of a $7 \times 4 \mathrm{~cm}$ mass, posterior to the gastric fundus, well-defined cystic lesion located superior and anterior to the left kidney and the spleen medially. 
Gastroscopy revealed a bulging deformity with extrinsic compression at the cardio-esophageal junction.

MRI and CT scans of the abdomen confirmed $55 \times 48 \mathrm{~mm}$ homogenous, septated cystic mass located posterior to the gastric fundus (Figure 1). Left kidney and spleen was clearly identified. To better evaluate the mass, patient underwent endoscopic ultrasonography that confirmed a hypoechoic mass with a slightly heterogeneous internal echo and regular margins located just below the gastroesophageal junction; the lesion measured about 5.5x5 $\mathrm{cm}$ and seemed to be contiguous to the fourth wall layer.

On exploratory laparotomy, there were two cystic masses measuring approximately $5 \times 4 \mathrm{~cm}$ and $3 \times 2 \mathrm{~cm}$, which was slightly adherent to anterior wall of stomach close to the greater curvature (Figure 2). Totally excision of cystic masses without resection of stomach was performed for a presumed gastric duplication cyst.

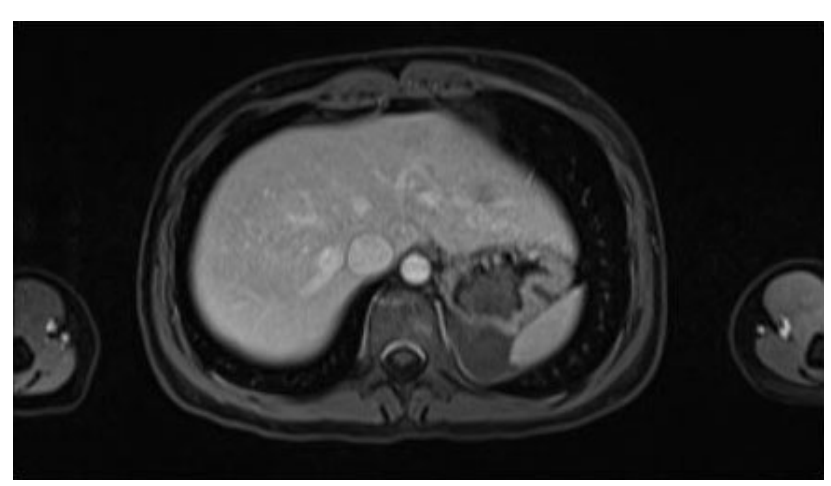

Figure 1. CT image shows a cystic lesion.

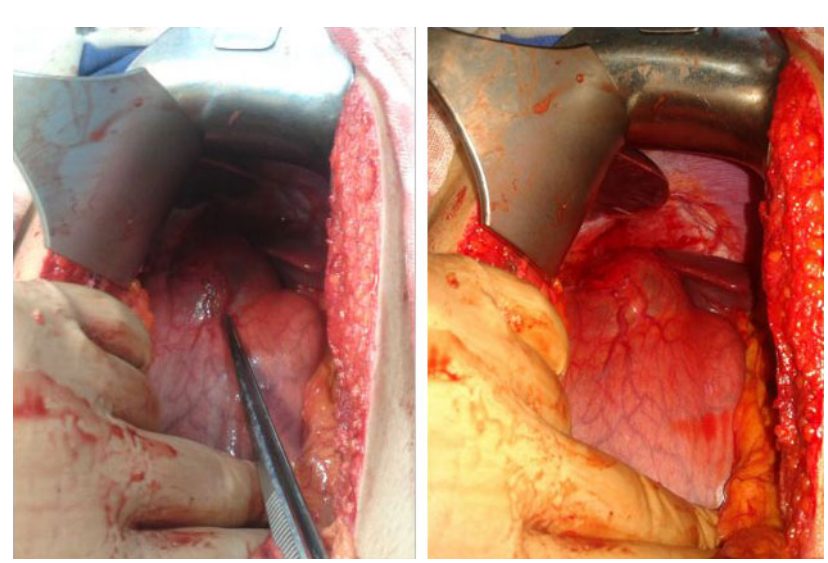

Figure 2. Photography shows duplication cysts.

Pathology confirmed a duplication cyst with gastric mucosa and no evidence of malignancy.
Patient's postoperative course was uneventful. She was discharged on the postoperative day 4 and is well and symptomless 6 months post-operatively.

\section{DISCUSSION}

GDCs are uncommon developmental anomalies found primarily in children, being rarely diagnosed in adults. However, diagnosis of the condition in an adult can be difficult, as it is usually asymptomatic, or the symptoms are nonspecific, with vague abdominal pain. Continued secretion of enzymes and hydrochloric acid into the duplication cyst may result in gastric ulceration, perforation of the gastric ulcer and the formation of a fistula into adjacent organs, which can result in gastrointestinal hemorrhage (4). Laboratory investigations of gastric duplication cysts are usually unremarkable. Most gastric duplications are localized along the greater curvature. They may have a cystic or tubular configuration and may or may not communicate with the gastric lumen. Noncommunicating cysts are more frequently encountered and can be identified as intramural defects with an irregular profile of the stomach at barium contrast radiography. Endoscopy may reveal a gastric mass with intact, erythematous or ulcerated overlying mucosa. CT and ultrasonography demonstrate the fluid content within the cyst, the former being the best method for studying such malformations and for establishing their size and connection with adjacent organs. Communicating cysts are extremely rare and easy to diagnose as they usually fill with barium during a barium swallow. CT may even reveal a double compartment stomach, directly visualizing the thickness of the duplication wall. The site of communication may also be located outside the stomach, in the duodenum or the esophagus (3).

Due to the risk of malignant transformation and other complications, treatment of GDC is surgical. Surgical excision is curative, provides symptomatic relief and prevents complications from the cyst. The basic principles of surgery are complete excision or else, depending on the localization, proximal or distal gastric resection may be performed.

\section{REFERENCES}

1. Jackson KL, Peche WJ, Rollins MD. An unusual presentation of a rectal duplication cyst. Int J Surg Case Rep 2012; 3(7): 314-5.

2. Singh JP, Rajdeo H, Bhuta K, Savino JA. Gastric duplication cyst: two case reports and review of the literature. Case Rep Surg 2013; 2013:605059.

3. Scatizzi M, Calistri M, Feroci F, Girardi LR, Moraldi L, Rubio CA, Moretti $R$, Nesi G. Gastric duplication cyst in an adult: case report. In Vivo 2005; 19(6):975-8.

4. Lee $L S$, Ong HS. A rare case of two synchronous gastric duplication cysts in an adult. Singapore Med J 2013; 54(4):91-2. 


\section{OLGU SUNUMU}

Q

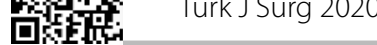

\section{Yetişkinlerde Nadir Görülen Çoklu Gastrik Duplikasyon Kistleri Olgu Sunumu}

Baris Zulfikaroglu ${ }^{1}$, Ozgur Akgul ${ }^{1}$, Mahir Ozmen ${ }^{2}$

1 Ankara Numune Eğitim ve Araştırma Hastanesi, Genel Cerrahi, Ankara, Türkiye

2 İstinye Üniversitesi Tıp Fakültesi, Genel Cerrahi, İstanbul, Türkiye

\section{ÖZET}

Bağırsak duplikasyonları, gastrointestinal sistem boyunca herhangi bir yerde ortaya çıkabilecek nadir gelişimsel anomalilerdir. Gastrik duplikasyon kistleri nadir görülen konjenital anomalilerdir ve yetişkinlerde nadiren teşhis edilir. Bununla birlikte, bir yetişkinde durumun teşhisi zor olabilir, çünkü genellikle asemptomatiktir veya semptomlar spesifik değildir. Burada cerrahi rezeksiyon ile başarılı bir şekilde tedavi edilen, yetişkinde nadir görülen semptomatik gastrik duplikasyon kistleri olgusu sunulmaktadır.

Anahtar Kelimeler: mide duplikasyon kisti, gastrointastinal duplikasyon, yetişkin, mide cerrahisi 